Table I. Demographics

\begin{tabular}{ccccccl}
\hline & \multicolumn{3}{c}{ Age } & \multicolumn{3}{c}{ Survival } \\
Patient & Sex & $(y r)$ & Stage & Status & $(w k)$ & Cause of death \\
\hline 1 & F & 69 & T3 N2 & DOD & 23 & Brain metastasis \\
2 & M & 62 & T3 N2 & DOD & 103 & Brain metastasis \\
3 & M & 53 & T3 N2 & DOD & 28 & Generalized \\
& & & & & & disease \\
4 & F & 64 & T3 N2 & DOD & 170 & Brain metastasis \\
5 & M & 52 & T3 N0 & DOC & 17 & Arrhythmia \\
6 & F & 82 & T3 N0 & DOC & 7 & MI \\
7 & M & 75 & T3 N0 & DOC & 5 & MVA \\
8 & M & 67 & T3 N0 & NED & 69 & \\
\hline
\end{tabular}

$D O D$, Died of disease; $D O C$, died of other causes; $N E D$, no evidence of disease; $M I$, Myocardial infarction; $M V A$, motor vehicle accident.

died of distant disease. Detection of N2 disease becomes of paramount importance in view of recent data suggesting that preoperative chemotherapy improves survival in such patients. ${ }^{4,5}$ Our follow-up on patients without involved mediastinal nodes is disappointing, because three of four patients died relatively soon after the operation of causes unrelated to their lung cancer. To our knowledge, none had evidence of disease at the time of death. Postoperative follow-up in the single patient who is free of disease is only 69.4 weeks.

In summary, resectable tumors invading the diaphragm are rare. Careful evaluation of the mediastinum with mediastinoscopy is important to detect N2 disease and select those patients for preoperative chemotherapy. Most tumors found to invade the diaphragm during surgery can be resected and the diaphragm closed primarily. The survival benefit of resecting the tumor in patients with diaphragmatic invasion is not clear. Because this is an unusual entity, it may be difficult to determine whether surgery is the adequate treatment modality. We believe that in patients without involved mediastinal nodes and in good general condition, diaphragmatic invasion should be treated by resecting the tumor en bloc with the diaphragm.

\section{REFERENCES}

1. McCaughan BC, Martini N, Bains MS, McCormack PM. Chest wall invasion in carcinoma of the lung: therapeutic and prognostic implications. J Thorac Cardiovasc Surg 1985;89: 836-41.

2. Martini N, Flehinger BJ, Zaman MB, Beattie EJ Jr. Results of resection in non-oat cell carcinoma of the lung with mediastinal lymph node metastases. Ann Surg 1983;198: 386-97.

3. Goldstraw P, Mannam GC, Kaplan DK, Michail P. Surgical management of non-small-cell lung cancer with ipsilateral mediastinal node metastasis ( $\mathrm{N} 2$ disease). $\mathrm{J}$ Thorac Cardiovasc Surg 1994;107:19-28.

4. Rosell R, Gomez-Codina J, Camps C, et al. A randomized trial comparing preoperative chemotherapy plus surgery with surgery alone in patients with non-small-cell lung cancer [see comments]. N Engl J Med 1994;330:153-8.

5. Roth JA, Fossella F, Komaki R, et al. A randomized trial comparing perioperative chemotherapy and surgery with surgery alone in resectable stage IIIA non-small-cell lung cancer [see comments]. J Natl Cancer Inst 1994;86:673-80.

\title{
PULMONARY ROOT TRANSLOCATION FOR BIVENTRICULAR REPAIR OF DOUBLE-OUTLET LEFT VENTRICLE WITH ABSENT SUBPULMONIC CONUS
}

\author{
Doff B. McElhinney, MS, V. Mohan Reddy, MD, and Frank L. Hanley, MD, San Francisco, Calif.
}

Double-outlet left ventricle (DOLV) is a rare form of malpositioned great arteries in which the aorta and the main pulmonary artery arise from the left ventricle in the presence of a malalignment ventricular septal defect.

From the Division of Cardiothoracic Surgery, University of California, San Francisco, San Francisco, Calif.

Received for publication Jan. 23, 1997; accepted for publication March 4, 1997.

Address for reprints: V. Mohan Reddy, MD, Division of Cardiothoracic Surgery, 505 Parnassus Ave., M593, San Francisco, CA 94143-0118.

J Thorac Cardiovase Surg 1997;114:501-3

Copyright (C) 1997 by Mosby-Year Book, Inc.

$0022-5223 / 97 \$ 5.00+0 \quad \mathbf{1 2 / 5 4 / 8 1 5 8 4}$
DOLV occurs as a spectrum and has been found with a variety of associated lesions, most commonly pulmonic or subpulmonic stenosis (or both), tricuspid valve anomalies, and hypoplasia of the right ventricle. ${ }^{1}$ Depending on the size and function of the right ventricle and tricuspid valve, along with the size and position of the ventricular septal defect, DOLV is usually amenable to biventricular repair. Traditionally, this has been accomplished by either an intraventricular baffle procedure or ventricular septal defect closure with conduit reconstruction of the right ventricular outflow tract (Rastelli repair). ${ }^{2,3}$ The former technique is not suitable for all forms of DOLV, especially those with a restrictive interventricular communication or subpulmonic stenosis. The Rastelli approach is suboptimal, especially in children, because they will almost inevitably outgrow their conduit and require conduit replace- 
Table I. Patients undergoing biventricular repair of DOLV

\begin{tabular}{|c|c|c|c|c|c|}
\hline \multirow[b]{2}{*}{ Patient } & \multirow[b]{2}{*}{ Age } & \multicolumn{2}{|c|}{ Pulmonary outflow obstruction } & \multirow[b]{2}{*}{ Morphology } & \multirow[b]{2}{*}{ Procedures performed } \\
\hline & & Type & $\begin{array}{l}\text { Gradient } \\
\text { (mm Hg) }\end{array}$ & & \\
\hline 1 & 9 days & $\begin{array}{l}\text { Subvalvular and } \\
\text { valvular }\end{array}$ & $*$ & $\begin{array}{l}\{\mathrm{S}, \mathrm{D}, \mathrm{D}\}, \mathrm{DOLV}, \text { absent conus, sub- } \\
\text { aortic VSD, PDA, single coronary } \\
\text { artery from anterior facing sinus }\end{array}$ & $\begin{array}{l}\text { RV-PA conduit, PA oversew, } \\
\text { VSD closure, PDA ligation }\end{array}$ \\
\hline \multirow[t]{2}{*}{2} & $24 \mathrm{yr}$ & $\begin{array}{l}\text { 1. Subvalvular } \\
\text { membrane and } \\
\text { mild valvular }\end{array}$ & $78 \dagger$ & $\begin{array}{l}\{\mathrm{S}, \mathrm{D}, \mathrm{L}\}, \mathrm{DOLV}, \text { absent conus, sub- } \\
\text { aortic VSD (s/p closure, with } \\
\text { residual leak) }\end{array}$ & $\begin{array}{l}\text { Pulmonary root translocation, } \\
\text { VSD closure, transannular PA } \\
\text { patch, conduit/shunt takedown }\end{array}$ \\
\hline & & 2. Conduit & $62 \ddagger$ & & \\
\hline 3 & $7.6 \mathrm{yr}$ & $\begin{array}{l}\text { Subvalvular and } \\
\text { mild valvular }\end{array}$ & 79 & $\begin{array}{l}\{\mathrm{S}, \mathrm{D}, \mathrm{D}\}, \mathrm{DOLV}, \text { subaortic conus } \\
\quad \text { (short), subaortic VSD }\end{array}$ & $\begin{array}{l}\text { Pulmonary root translocation, } \\
\text { VSD closure, shunt takedown }\end{array}$ \\
\hline
\end{tabular}

$\{S, D, D / L\}$, Segmental anatomy.

*Diagnosis was by echocardiography, and an accurate gradient could not be estimated could not be estimated because of the presence of a patent ductus arteriosus (PDA).

$†$ Patient 2 had previously undergone ventricular septal defect (VSD) closure with the pulmonary valve committed to the left ventricle; this gradient is the left ventricle-pulmonary artery (PA) gradient.

FIn addition to the main PA arising from the left ventricle, pulmonary blood flow was supplied by two right ventricle (RV) to PA conduits placed in parallel at successive operations; this gradient is the RV-PA pressure difference.

ment. ${ }^{4}$ In addition, valve function deteriorates in valved tissue conduits used in the pulmonary circulation, and the right ventricle does not always tolerate chronic pulmonary insufficiency well. ${ }^{5}$ Experience with the Ross procedure has shown that the pulmonary root can be excised and relocated without compromising valve integrity. ${ }^{6}$ Given the success of this procedure, it is likely that DOLV can be repaired by translocating the pulmonary root from the left ventricle to the right ventricle with similar efficacy. Indeed, two reports (a total of three patients) have described biventricular repair of DOLV with subpulmonic or bilateral conus by this technique.,

Since 1993, we have performed two-ventricle repair of DOLV in three patients. Demographic and diagnostic features are summarized in Table I. All patients had pulmonic or subpulmonic stenosis (or both), two normalsized ventricles, and normal atrioventricular valve morphology and function. In the first of these patients (patient 1 ), who was referred for surgical treatment at 9 days of age with moderate-severe valvular/annular stenosis, the malalignment septal defect was closed to the aorta, the native pulmonary artery was oversewn, and a $10 \mathrm{~mm}$ pulmonary allograft conduit was used to establish right ventriclepulmonary artery continuity. The other two patients, both of whom had no subpulmonic conus, underwent translocation of the pulmonary valve and artery from the left ventricle to the right ventricle (Fig. 1). Patient 2 was referred to us at 24 years of age after having undergone two previous systemic-pulmonary artery shunts and two Rastelli procedures, with both great arteries committed to the left ventricle and conduit pulmonary outflow tract reconstruction (4 and 6 years previously, with the second conduit placed in parallel with the first). Patient 3 was 7.6 years old at the time of the operation and had also undergone four previous procedures, including three systemic-pulmonary artery shunts and, 4 years earlier, a bidirectional cavopulmonary shunt. The pulmonary root was translocated and the bidirectional cavopulmonary shunt was left in place.
No early deaths or complications occurred. At follow-up periods of 48,39 , and 18 months, all patients were alive and in New York Heart Association class I. Follow-up echocardiography showed normal biventricular function and no atrioventricular or semilunar valve stenosis or insufficiency, except for mild conduit insufficiency and a $36 \mathrm{~mm} \mathrm{Hg}$ conduit gradient in patient 1 and trivial pulmonary insufficiency in patient 2 . No patients underwent postoperative catheterization during the follow-up period. Patient 2 had given birth to a healthy baby boy, who had no evidence of congenital heart disease.

Discussion. DOLV has been shown to occur with all forms of conal arrangement: subpulmonic, subaortic, bilaterally present, and bilaterally absent. One of the ways in which our two patients who underwent pulmonary root translocation differ from previously reported cases is that a subpulmonic conus was absent in both, whereas a subpulmonic or bilateral conus has been present in all three of the previous patients. ${ }^{3,7}$ Although the subpulmonic conus may be shorter than usual in DOLV, pulmonary valve excision in this setting is technically similar to the approach used in the Ross procedure. Absence of a subpulmonic conus makes for a more difficult procedure than aortic valve replacement with a pulmonary autograft, primarily because it necessitates careful dissection of the deeply set pulmonary valve from the atrioventricular valve(s) with which it is in continuity.

Although results of right ventricular outflow tract conduit reconstruction in DOLV have been favorable, ${ }^{2}$ we believe that pulmonary root translocation from the left ventricle to the right ventricle is a preferable approach. The primary advantage of this technique is that native tissue is used for right ventricular outflow tract reconstruction. On the basis of outcomes after pulmonary autograft aortic valve replacement ${ }^{6}$ translocating the native root from the left ventricle to the right ventricle will most likely translate into growth potential and preserved valve function. These factors will contribute to a decreased likelihood of reoperation related to the right ventricular outflow tract and right ventricular 


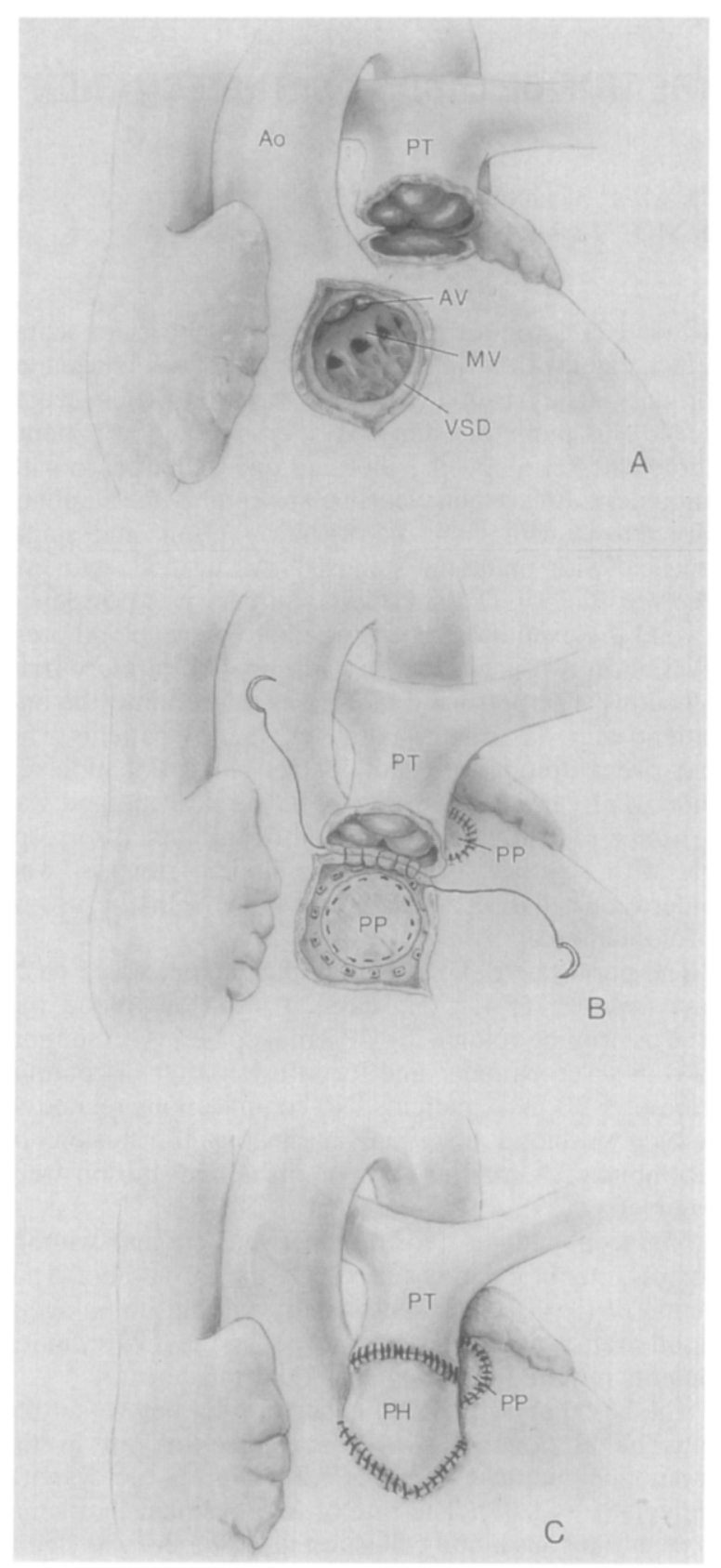

Fig. 1. A, The pulmonary root $(P T)$, positioned to the left and slightly posterior to the aorta $(A O)$, is being excised. Through a right ventriculotomy and the ventricular septal defect $(V S D)$, the aortic $(A V)$ and mitral $(M V)$ valves can be visualized in the left ventricle. B, Polytetrafluoroethylene patches $(P P)$ have been used to close the ventricular septal defect and the defect in the left ventricle from excision of the pulmonary root. The posterior rim of the root $(P T)$ is sutured to the superior aspect of the right ventriculotomy. $\mathbf{C}$, The procedure is completed by creating a hood $(\mathrm{PH})$ across the anterior aspect of the anastomosis. dysfunction related to pulmonary insufficiency. ${ }^{4,5}$ In cases of mild pulmonary valve/anulus hypoplasia, such as in patient 2 in the present series, relief from obstruction can be achieved with a limited transannular patch or with a supplementary bidirectional cavopulmonary shunt to unload the right ventricle. When more moderate pulmonary stenosis is present, pulmonary root translocation may still be the optimal approach if the outflow obstruction can be eliminated by placing a bidirectional cavopulmonary shunt with or without a limited transannular patch. One of the unique aspects of our two cases of pulmonary root translocation for DOLV is that additional means were taken to relieve pulmonary outflow obstruction in both patients, including a limited transannular patch in one and maintenance of a bidirectional cavopulmonary shunt in the other. These modifications, neither of which has been previously described, demonstrate that pulmonary root translocation can be undertaken in patients with pulmonary outflow obstruction or a right heart that may be incapable of supporting an entire cardiac output. However, in patients with severe outflow tract obstruction, such as our patient 1 , who underwent surgery at 9 days of age, a standard Rastelli-type procedure may still be the best option.

Regarding the timing of pulmonary root translocation for DOLV, the best option is probably to perform primary repair in infancy, as has been the case in two of the previously reported cases. ${ }^{3,7}$ However, as we have demonstrated in this report, pulmonary root translocation may also be performed successfully in patients who have undergone multiple previous operations, including Rastelli repair, in which case the pulmonary root may be translocated to the previous conduit anastomosis site.

\section{REFERENCES}

1. Van Praagh R, Weinberg PM, Srebro JP. Double-outlet left ventricle. In: Adams FH, Emmanouilides GC, Riemenschneider TA, editors. Heart disease in infants, children and adolescents. 4th ed. Baltimore: Williams \& Wilkins; 1989. p. 461-85.

2. Bharati S, Lev M, Stewart R, McAllister HA, Kirklin JW. The morphologic spectrum of double outlet left ventricle and its surgical significance. Circulation 1978;58:558-65.

3. DeLeon SY, Ow EP, Chiemmongkoltip P, Vitullo DA, Quinones JA, Fisher EA, et al. Alternatives in biventricular repair of double-outlet left ventricle. Ann Thorac Surg 1995;60: 213-6.

4. Reddy VM, Rajasinghe HA, McElhinney DB, Hanley FL. Performance of right ventricle to pulmonary artery conduits after repair of truncus arteriosus: a comparison of Dacron housed porcine valves and cryopreserved allografts. Semin Thorac Cardiovasc Surg 1995;7:133-8.

5. Ilbawi MN, Idriss FS, DeLeon SY, Muster AJ, Gidding SS, Berry TE, et al. Factors that exaggerate the deleterious effects of pulmonary insufficiency on the right ventricle after tetralogy repair. J Thorac Cardiovasc Surg 1987;93:36-44.

6. Reddy VM, Rajasinghe HA, McElhinney DB, van Son JAM, Black MD, Silverman NH, et al. Extending the limits of the Ross procedure. Ann Thorac Surg 1995;60:S600-3.

7. Chiavarelli M, Boucek MM, Bailey LL. Arterial correction of double outlet left ventricle by pulmonary artery translocation. Ann Thorac Surg 1992;53:1098-100. 